Відтак, рефлексивний складник є необхідним у структурі інтерпретаційної компетентності студентів педагогічного коледжу, показниками якої нами визначено вміння інтерпретувати й аналізувати свою діяльність і діяльність довколишніх людей та вміння інтерпретувати й аналізувати діяльність молодших школярів.

Важливою професійною якістю сучасного вчителя $\epsilon$ його інтерпретаційна компетентність, що допомагає вдосконалювати навчально-виховний процес, грунтуючись на педагогіці розуміння. Набуття майбутніми вчителями початкової школи знань щодо інтерпретаційної компетентності, оволодіння ними необхідними вміннями й навичками інтерпретаційної діяльності буде відбуватись ефективно, якщо в навчально-виховний процес педагогічних коледжів будуть упроваджені відповідні педагогічні умови, що становить перспективу наших подальших досліджень.

\title{
Література
}

1. Бондаревська Е. В. Парадигмальний підхід до розробки змісту ключових педагогічних компетенцій / Е. В. Бондаревська, С. В. Кульневич // Педагогіка. 2004. - № 10. - С. 23-31. 2. Власова О. І. Педагогічна психологія:[навч. посібник] / О. І. Власова. - К., 2005. - 315 с. 3. Закирова А. Ф. Теоретические основы педагогической герменевтики: [монография] / А. Ф. Закирова. - Тюмень : Изд-во Тюменского гос. ун-та, 2001. - 152 с. 4. Ищенко Е. Н. Новая парадигма интерпретации в дискурсивном поле современной философии / Е. Н. Ищенко // Вестник МГУ. Серия 7 Философия. - 2004. - № 6. - С. 62-74. 5. Кан-Калик В. А. Педагогическая деятельность как творческий процесс / В. А. Кан-Калик. -М., 1976. 286 с. 6. Кацова Л. І. Формування професійного інтересу у майбутніх учителів у процесі педагогічної практики: автореф. дис. на здобуття наук. ступеня доктора пед. наук: спеціальність 13.00.04 «Теорія та методика професійної освіти» / Л. І. Кацова. Харків, 2005. - 19 с. 7. Корепанова Н. В. Профессионально-личностное становление и развитие педагога / Н. В. Корепанова// Педагогика. - 2003. - № 3. - С. 66-71. 8. Костюк А. Г. Восприятие мелодии. Мелодические параметры процесса восприятия музыки / А. Г. Костюк. - К. : Наукова думка, 1986. - 189 с. 9. Кузнєцова О. А. Потреба у професійно-орієнтованій рефлексії як умова формування самовизначення майбутнього вчителя / О.А.Кузнєцова // Науковий вісник Південноукраїнського державного педагогічного університету імені К. Д. Ушинського: зб. наук. пр. - 2004. № 5-6. - С. 67-74. 10. Пономарев Я. А. Психология творчества: общая, дифференциальная, прикладная / Я. А. Пономарев. - М. : Наука, 1990. - 222 с.

УДК 37.013

Вікторія Хребтова

\section{РОЗВИТОК ІДЕЙ ПОЛІКУЛЬТУРНОГО ВИХОВАННЯ В КОНТЕКСТІ СВІТОВОГО ДОСВІДУ}

Хребтова В. В. Розвиток ідей полікультурного виховання в контексті світового досвіду.

У статті з'ясовується питання про зародження й перспективи розвитку полікультурного виховання, аналізується стан названої проблеми в сучасній педагогіці, характеризується загальнопедагогічне питання сутності полікультурного виховання, визначається специфіка та основні етапи розвитку полікультурного виховання відповідно до нової освітньої парадигми.

Ключові слова: полікультурне виховання, поліетнічне й полікультурне суспільство, культурні цінності, плюралізм культур, мультиідентична особистість.

Хребтова В. В. Развитие идей поликультурного воспитания в контексте Педагогіка вищої та середної иколи. - 2014. - Вип. 41 
мирового опыта.

В статье освещается вопрос о зарождении и перспективах развития поликультурного воспитания, анализируется состояние исследуемой проблемы в современной педагогике, характеризуется общепедагогический вопрос сущности поликультурного воспитания, определяется специфика и основные этапы развития поликультурного воспитания в соответствии с новой образовательной парадигмой.

Ключевые слова: поликультурное воспитание, полиэтническое и поликультурное общество, культурные ценности, плюрализм культур, мультиидентичная личность.

Khrebtova V. V. The development of the ideas of multicultural education in the context of international experience.

The problem of the origin and perspectives of the development of multicultural education is elucidated, the position of the investigated issue in the modern pedagogics is analysed, the general pedagogic question of the essence of multicultural education is characterized and the specificity and principal stages of the development of multicultural education in compliance with the new educational paradigm are defined in the article.

Key words: multicultural education, multiethnical and multicultural society, cultural values, pluralism of cultures, multi-identical personality.

У світі сучасних концепцій виховання в умовах гуманізації та демократизації суспільства підвищується соціальна роль творчої особистості- носія нових моральних якостейта цінніснихорієнтацій, якій притаманний високий рівень духовності та загальної культури, здатність до саморозвитку та самовдосконалення. На сучасному етапі процесу глобалізації світової цивілізації виникає необхідність визначення стратегії виховання полікультурної особистості, яка володіє як мінімум трьома мовами, поважає культуру і традиції інших народів. Настав час активної боротьби за полілінгвістичну освіту в Європі, зорієнтовану на поширення й поглиблення міжкультурних зв'язків між країнами.

Світова співдружність опікується розробленням нової освітньої стратегіїполікультурної освіти. Сутність їі полягає в підготовці молодого покоління до життя й ефективної діяльності в умовах поліетнічного й полікультурного суспільства. Проблема полікультурної освіти в Україні нині особливо актуальна, оскільки Україна $є$ багатонаціональною державою, що розташована на межі європейської й азійської цивілізацій, а її регіони мають унікальні соціально-економічні й етнокультурні особливості.

Mema cmammi - визначити та проаналізувати, як історично формується думка щодо специфіки та основних етапів розвитку полікультурної освіти, висвітлити стан названої проблеми в сучасній педагогіці.

Ідея «полікультурності» і полікультурної освіти - реальність не лише сучасної епохи, це поняття пов'язано з іменами багатьох видатних науковців, педагогів, діячів культури минулого та сьогодення. У XVI ст. відомий чеський педагог Ян Амос Коменський розробив програму «Пампедія», яка грунтується на принциповому визнанні спільності людей, їхніх потреб, прагнень та переконань. Пампедія - це програма універсального виховання всього людства, яка не залишається поза увагою й донині. Я. А. Коменський уважає, що насамперед доцільно сприяти формуванню в молодшого покоління уміння жити у злагоді з іншими, виконувати взаємні обов'язки, поважати та любити людей [5, с. 395].

Безумовну цінність для розуміння значення полікультурної освіти у становленні особистості мають погляди П. Каптерева, який уперше пропонує ідею про єдність національного й загальнолюдського в педагогіці й зазначає, що полікультурна освіта 
має бути одним з основних принципів професійної діяльності вчителів. Безперечно, ми маємо всі підстави визнавати П. Каптерева одним із провісників полікультурної освіти, який уважає, що в дитини необхідно розвивати почуття приналежності до всього людства. Науковець, ставлячи риторичне питання, наголошує на тому, що «рідний народ - єдиний носій справжньої культури, а інші народи мають служити йому» [3, с. 307]. На його думку, педагогічна діяльність на початковому етапі здійснюється на основі національного ідеалу,а вже потім трансформується у площину досягнення ідеалу загальнолюдського. У вихованні, як підкреслює науковець, «потрібно звертатися не до одного народу, а до багатьох, розглядати їхні ідеали й доповнювати те, чого не вистачає своєму національному ідеалу цінними властивостями інших народів, народне треба поєднувати з іноземним, з усенародним і загальнолюдським» [3, с. 56].

Для розуміння сутності полікультурної освіти особливе значення мають ідеї також таких відомих дослідників початку XX ст., як М. Бахтін, Л. Виготський, M. Реріх. Найважливішою методологічною основою полікультурної освіти $\epsilon$ ідеї М. Бахтіна про культуру як діалог, де людина розглядається як унікальний світ культури, яка взаємодіє 3 іншими особистостями - культурами, які творять себе у процесі цієї взаємодії і впливають на інших. Цей підхід реалізується в сучасній педагогіці як ідея діалогу культур.

Важливі висновки для обгрунтування полікультурної освіти містяться в культурно-історичній теорії розвитку поведінки і психіки Л. Виготського, згідно 3 якою витоки і детермінанти психічного розвитку лежать в історичному розвитку культури. Науковець стверджує, що будь-яка функція в культурному розвитку людини з'являється спочатку в соціальному, а потім у психологічному плані. Це свідчить про те, що полікультурне виховання не передається генетично, а формується. Л. Виготський переконаний, що положення щодо провідної ролі соціокультурного контексту в розвитку людини передбачає врахування у становленні особистості конкретних реалій, визначає значимість у формуванні свідомості учня навколишнього середовища, відносин з людьми, ставлення до тих чи тих культурних цінностей [2].

Особливе місце в розумінні сутності, мети й завдань полікультурної освіти мають ідеї російського мислителя М. Реріха про «благодійний синтез», під яким науковець розуміє «єднання культур як основний чинник взаєморозуміння й позитивного співробітництва представників етнокультурних систем».

Відомий американський спеціаліст 3 полікультурного виховання, доктор філологічних наук, професор Вищої школи освіти (університет Масачусетс) Соня Ніето розглядає полікультурну освіту як «процес, що кидає виклик расизму, відхиляє інші форми дискримінації в навчальних закладах і суспільстві, але визнає й стверджує плюралізм (етнічний, расовий, мовний, релігійний, економічний, родовий тощо), що відображають студенти, їхні спільноти, вчителі. Полікультурна освіта декларує демократичні принципи соціальної справедливості» [10].

Нині на основі знань і досвіду з окресленої проблеми сформувалась порівняно молода наукова галузь - полікультурна педагогіка.

Починаючи 3 60-х років минулого століття, американська педагогіка широко використовує поняття «полікультурна освіта» (multicultural education). Американський науковець Джеймс Бенкс - директор Центру мультикультурної освіти (університет Вашингтон), один із провідних міжнародних експертів у цій галузі- розробив концепцію полікультурної освіти, в основу якої покладено розуміння культури й тієї ролі, яку етнічна належність відіграє в американському суспільстві. Висновок, до 
якого дійшов науковець, має такі положення: американці діють у межах кількох культур, включаючи основну й різноманітні етнічні. Головна мета полікультурної освіти - допомогти підростаючим поколінням усвідомити свою належність до певної культури, розвинути розуміння й сприйняття інших культур, підвищити рівень міжкультурної компетентності, допомогти якомога повніше реалізувати свій індивідуальний людський потенціал [6].

Уперше поняття полікультурної освіти було подано в Міжнародному педагогічному словнику як освітню ситуацію, «коли носій однієї культурної системи вступає в контакт із цінностями іншої чи інших культур, представлених у певному навчальному закладі» [8]. Згодом це поняття зазнало суттєвої еволюції. Найповніше, на наш погляд, поняття полікультурної освіти розкрито в Міжнародній енциклопедії освіти. Енциклопедія наводить таке визначення поняття: «Полікультурне виховання це виховання, що передбачає організацію і зміст педагогічного процесу, у якому подано дві або більше культури, що різняться за мовою, етнічною, національною або расовою ознаками» [9].

Для характеристики полікультурної освіти використовувалися й такі поняття, як поліетнічна освіта, кроскультурна освіта, міжкультурна освіта, інтеркультурна освіта, мультикультурна освіта.

Американські викладачі говорять про те, що полікультурна освіта - це освіта, чиєю цінністю є плюралізм культур. Полікультурна освіта орієнтує школи на культурне збагачення всіх дітей і підлітків, на розроблення програм зі збереженням й розширенням культурного плюралізму; визнає розходження в культурі як факт життя американського суспільства, підтверджуючи, що культурна багатоманітність $є$ цінним ресурсом, який варто зберігати й примножувати; грунтується на знанні й розумінні відмінностей у культурі. Важливішим тут $є$ визнання відмінностей у культурі різних людей, а ефективна навчально-виховна програма робить рівність культур реальною й значущою [7, с. 21].

Розуміння полікультурності починається 3 усвідомлення різноманітності навколишнього світу, усвідомлення того, що і країна, у якій ти живеш, і весь світ населені представниками різних етнічних $\mathrm{i}$ культурних груп. Якщо школа зорієнтована на індивідуальні потреби дитини, вона має забезпечувати таку освіту, яка б допомагала представникам таких культур не тільки існувати, але й жити разом на основі гармонійної взаємодії. Водночас освіта покликана допомагати учням здобувати знання й уміння жити в демократичному суспільстві. Саме полікультурна освіта може сприяти виконанню цих завдань. Полікультурна освіта має бути процесом, а не якоюсь одноразовою програмою [1].

На думку Є. Ковальчука, основною ідеєю полікультурної освіти є діалог і взаємодія різноманітних культур, які передбачають, що найповніше власна культура усвідомлюється тільки за взаємодії, діалогу різних культур, коли стають видимими й зрозумілими особливості кожної окремої культури. Взаємодія культур у сучасних умовах характеризується насамперед тим, що загальнолюдське допомагає усвідомлювати об'єктивну цінність «свого», глибше розуміти його своєрідність на основі порівняння, виявляти нове у функціонуванні й прогнозувати розвиток. У процесі взаємодії культур зростає обсяг сприйнятих цінностей, отже, змінюється й сам характер сприйняття: цей характер стає дальновиднішим, відбиває властивості об'єкта в усій його багатогранності й глибині. Ізольованість, прагнення замкнутості можуть сприяти поступовій деградації культури. Культура, що блокує контакти, зв'язки з іншими культурами, зберігає свою самобутність дорогою ціною, адже може 
виявитися в результаті такої самоізоляції поза рівнем світової культури [4].

Ураховуючи глибокі та динамічні зміни, що відбуваються у світі в останні десятиліття, світова педагогічна думка шукає відповідні шляхи розвитку освіти. Саме освіта в полікультурному вияві повинна сприяти тому, щоб людина усвідомлювала своє національне коріння і щоб прищепити їй повагу до інших культур. Отже, щоб пізнати народ, треба пізнати його культуру. Тому можна зробити висновок, що полікультурність - це елемент загальної культури. Створення культури у свідомості людини поступово наближає іiі до сприйняття себе як мікрокультури, визначає межі іiі особистого місця у просторі великої культури.

Одним 3 головних способів організації полікультурного виховання $\epsilon$ забезпечення культурологічної спрямованості філологічної освіти та введення полікультурного компонента в різні навчальні дисципліни. Лідирує при цьому двомовне та багатомовне навчання, яке не тільки сприяє комунікації, але й дозволяє долучатися до різних способів мислення, відчуття, поведінки. Іноземна мова $є$ не об'єктом вивчення, а засобом отримання знань, i, як наслідок, виникає подвійний ефект - одночасно таким шляхом набуваються нові знання і мовленнєві навички. Потрібно визначити зародження нової фази вивчення іноземних мов, коли людина розпочинає вивчати іноземну мову як важливе джерело культури.

Будучи близьким до ідеї гуманного міжнаціонального співіснування, полікультурне виховання відкидає консолідацію на базі корпоративної ворожнечі, протистояння іншим соціальним групам, цивілізаціям та духовним цінностям. 3 одного боку, полікультурне виховання нівелює формування людини позанаціональної культури, 3 іншого,- сприяє зародженню мультиідентичній особистості як зосередження та перетин декількох цивілізацій.

Отже, поступове усвідомлення необхідності полікультурного виховання тими, хто навчає, і тими, хто навчається, - це вже обнадійливий початок. Соціальна значущість і практична необхідність полікультурного виховання сучасної молоді, а також наявність суперечності в досягненні кінцевої мети в мікро- та макросоціумі надає підстави для подальшого вивчення цієї проблеми.

\section{Література}

1. Абібуллаєва Г. С. Деякі аспекти полікультурної освіти / Г. С. Абібуллаєва // Педагогіка і психологія. - 2006. - № 1. - С. 75-84.2. Выготский Л. С. Избранные психологические исследования / Л. С. Выготский. - М. : Педагогика, 1956. - 450 с. 3. Каптерев П. Ф. Избранные педагогические сочинения/ П. Ф. Каптерев. - М. : Мысль, 1982. - 421 с.4. Ковальчук Е. С. Поликультурное воспитание в современном школьном образовании России : дис. ... канд. пед. наук : 13.00.01 / Евгений Сергеевич Ковальчук. - К., 2004. - 168 с. 5. Коменский Я. А. Избранные педагогические сочинения: В 2 т.- М. : Педагогика, 1982. - Т. 2. - 576 c. 6. Banks James A. Multicultural education characteristics and goals // Bancs J. A., Bancs A. M. // Multicultural education: Issues and Perspectives. - Boston : Allyn and Bacon, 1989. - P. 15-20.7. Hunter William A., ed. Multicultural Education Through Competency. - Based Teacher Education «Antecedents to Development of and Emphasis on Multicultural Education»// Washington D. C. American Association for Colleges of Teacher Education, 1974. - 89 p. 8. International Dictionary of Education. - London: Kogan Page, 1977.273 p.9. International Encyclopedia of Education.- Vol. 7. Oxford, Rergamon Press, 1994. - P. 40-64. 10. Nieto Sonia. Affirming Diversity: the Sociopolitical Context of Multicultural Education / Sonia Nieto. - London: Longman, 2000. - 305 p. 